\title{
IMPLEMENTASI ORGANIZATIONAL CULTURE ASSESSMENT INSTRUMENT (OCAI) UNTUK PEMETAAN BUDAYA ORGANISASI PT. SEMEN INDONESIA (PERSERO) TBK SEBAGAI RUJUKAN WINNING CULTURE
}

\author{
Nur Elisa Faizaty \\ Departemen Manajemen, Universitas Internasional Semen Indonesia \\ Gresik, Indonesia, nur.faizaty@uisi.ac.id \\ Reza Melynda Oktavia \\ Departemen Manajemen, Universitas Internasional Semen Indonesia \\ Gresik, Indonesia, rezamel32@gmail.com \\ Mirza Dwinanda Ilmawan \\ Departemen Manajemen, Universitas Internasional Semen Indonesia \\ Gresik, Indonesia, mirza.ilmawan@uisi.ac.id
}

\begin{abstract}
Background - Industrial revolution 4.0 make competition between countries will be more competitive. This competition was also felt by PT Semen Indonesia (Persero) Tbk, which is the market leader in the cement industry in Indonesia. Company that implement corporate culture very well, was reached hundred times growth that companies that don't consider corporate culture s main concern.
\end{abstract}

Diterima : 13 November 2019 Direview : 30 November 2019 Direvisi : 04 Desember 2019

Disetujui : 27 januari 2020

Aim - This study aims to mapping the organization culture through OCAI (Organizational Culture Assessment Intstrument.

Design / methodology / approach - The sampling technique uses the proportionate stratified random sampling method which consists of 6 General Managers, 20 Senior Managers, 34 Head Section, 33 Head Teams and 13 Staffs. The instrument used in this study was the Organizational Culture Assessment Intstrument (OCAI), which maps organizational culture into four types of organizational culture through six-dimensional measurement, namely dominant characteristics, organizational leadership, employee management, organizational adhesives, and success criteria. Data collection techniques used are questionnaires.

Finding - The results of the research show that the dominant culture now perceived is hierarchical culture, and the expected dominant culture is clan culture. The results of the validation from the expert stated that as a state-owned corporation that has a global go vision, the clan culture adopted by employees is irrelevant. Culture that is applied to be more suitable for going global is market culture as the main culture or common culture. Whereas the second culture or dominant sub-culture is a type of cultural hierarchy.

Research implication - The existence of this mapping is expected to be an input to management, how management can create a more dominant competitive culture and unite employees with a culture that has been determined by management.

Keywords: Corporate Culture, OCAI. PT. Semen Indoensia (persero) Tbk. 


\begin{abstract}
ABSTRAK
Latar belakang - Revolusi industri 4.0 membuat persaingan antar negara akan semakin kompetitif. Persaingan ini juga dirasakan oleh PT Semen Indonesia (Persero) Tbk, yang merupakan pemimpin pasar dalam industri semen di Indonesia. Perusahaan yang menerapkan budaya perusahaan dengan sangat baik, telah mencapai pertumbuhan seratus kali lipat dari perusahaan yang tidak mempertimbangkan budaya utama perusahaan.

Tujuan - Penelitian ini bertujuan untuk memetakan budaya organisasi melalui OCAI (Instrumen Penilaian Budaya Organisasi).

Desain / metodologi/ pendekatan - Teknik pengambilan sampel menggunakan metode stratified random sampling proporsional yang terdiri dari 6 Manajer Umum, 20 Manajer Senior, 34 Kepala Bagian, 33 Kepala Tim dan 13 Staf. Instrumen yang digunakan dalam penelitian ini adalah Organizational Culture Assessment Intstrument (OCAI), yang memetakan budaya organisasi menjadi empat jenis budaya organisasi melalui pengukuran enam dimensi, yaitu karakteristik dominan, kepemimpinan organisasi, manajemen karyawan, perekat organisasi, dan kriteria keberhasilan. Teknik pengumpulan data yang digunakan adalah kuesioner.

Temuan - Hasil penelitian menunjukkan bahwa budaya dominan yang saat ini dirasakan adalah budaya hierarkis, dan budaya dominan yang diharapkan adalah budaya suku. Hasil validasi dari pakar menyatakan bahwa sebagai perusahaan milik negara yang memiliki visi go global, budaya klan yang diadopsi oleh karyawan tidak relevan. Budaya yang diterapkan agar lebih cocok untuk go global adalah budaya pasar sebagai budaya utama atau budaya bersama. Sedangkan budaya kedua atau subbudaya dominan adalah jenis hierarki budaya.

Implikasi penelitian - Keberadaan pemetaan ini diharapkan dapat menjadi input bagi manajemen, bagaimana manajemen dapat menciptakan budaya kompetitif yang lebih dominan dan menyatukan karyawan dengan budaya yang telah ditentukan oleh manajemen.
\end{abstract}

Kata kunci: Budaya Organisasi, OCAI, PT. Semen Indonesia Tbk.

\section{PENDAHULUAN}

Dalam momentum revolusi industri 4.0, kompetisi antar negara akan semakin ketat. Kompetisi ini juga dirasakan oleh PT Semen Indonesia (Persero) Tbk. yang merupakanpemimpin pasar di industri persemenan di Indonesia. Menteri BUMN Rini Soemarno meminta agar BUMN termasuk PT Semen Indonesia (Persero) Tbk bisa menjadi pemain global, dan dalam dua hingga tiga tahun ke depan perseroan harus bisa masuk jajaran perusahaan terbaik versi Fortune 500.

Yunanto selaku Direktur SDM dan

Hukum PT Semen Indonesia (PT. SI) periode 2017-2022 mengungkapkan bahwa saat ini visi perusahan mengarah pada world class company. Manusia sebagai aset yang paling berharga dalam perusahaan, harus bergerak dengan mindset yang sama untuk memenangkan persaingan. Berdasarkan salah satu penelitian dari Harvard University dalam Sinergi edisi 18, perusahaan yang menerapkan corporate culture dengan sangat baik akan mengalami pertumbuhan beratus-ratus kali lipat dibanding perusahaan yang tidak fokus pada corporate culture. Oleh karena itu, bagi perusahaan yang ingin menuju world class company, membangun budaya 
perusahaan unggul alias winning culture adalah jawabannya.

Tidak ada satupun tipe budaya organisasi yang terbaik yang dapat berlaku universal. Hal terpenting adalah organisasi harus mengetahui peta budaya organisasi saat ini dan mengevaluasinya apakah budaya yang berlaku tersebut dapat menyesuaikan tantangan yang dihadapi organisasi. Organizational Culture Assessment Instrument (OCAI) merupakan instrumen yang dikembangkan oleh Cameron \& Quinn (2011) untuk memberi penilaian dan mengidentifikasi peta budaya perusahaan saat ini dan keinginan perubahan organisasi. Instrumen ini juga terbukti akurat dalam mendiagnosis aspekaspek penting organisasi yang berkenaan dengan budaya.

Sebelumnya telah ada penelitian mengenai analisis budaya organisasi di PT Semen Indonesia (Persero) Tbk. menggunakan instrumen OCAI, yang dilakukan oleh dan Gustomo di PT. SI Gresik. Persamaan penelitian ini adalah sama-sama meneliti dan memetakan budaya organisasi di PT Semen Indonesia (Persero) Tbk. menggunakan metode OCAI. Keterbarusan dari penelitian ini adalah pertama, menggunakan visi misi baru perusahaan sebagai dasar analisis karena visi misi PT. SI telah diperbaharui sejak 2 tahun terakhir. Dengan visi baru sebagai perusahaan Go Global, analisis peta budaya organisasi akan menghasilkan peta budaya yang berbeda dengan periode sebelumnya. Kedua, penelitian ini bertujuan untuk megetahui peta budaya PT. Semen Indonesia dalam konteks kesiapan untuk memasuki era revolusi industri 4.0 dan menyiapkan PT. SI sebagai organisasi Go Global. Revolusi industri 4.0 menyebabkan lingkungan bisnis berubah, terutama untuk perusahaan yang akan Go Global, sehingga perusahaan perlu membaca ulang budaya organisasinya untuk mengevaluasi apakah budaya yang berlaku tersebut dapat menyesuaikan tantangan yang dihadapi dan mencapai visi misinya. Ketiga, ruang lingkup populasi yang lebih luas yaitu yaitu di Gresik, Tuban, Rembang.

Pertanyaan penelitian dalam penelitian ini adalah Bagaimana peta budaya PT Semen Indonesia (Persero) Tbk. yang dominan saat ini dan yang diharapkan berdasarkan persepsi dari karyawan PT Semen Indonesia (Persero) Tbk. dengan metode OCAI (Organizational Culture Assessment Instrument) untuk mencapai target program Winning Culture sebagai pondasi menuju World Class Company?

\section{TINJAUAN PUSTAKA}

Organizational Culture Assessment Instrument (OCAI)

OCAI sebagai instrumen yang digunakanuntuk memberi penilaian 
terhadap budaya perusahaan saat ini dan memetakan keinginan perubahan organisasi melalui 4 budaya organisasi yaitu Clan, Adocrachy, Market dan Hierarchy. Instrumen ini mampu melihat kesenjangan antara budaya yang sebenarnya akan dituju oleh perusahaan dengan budaya yang saat ini diyakini. OCAI adalah instrumen yang dapat membantu mendiagnosis kekuatan budaya, jenis budaya dan budaya organisasi. Masing-masing alternatif budaya organisasi, dilihat melalui enam dimensi kunci budaya organisasi, yaitu:

1. Karakteristik Dominan

Dimensi ini menunjukan karakteristik apa yang mudah dilihat dan paling menonjol di dalam sebuah lingkungan organisasi.

2. Kepemimpinan Organisasi

Dimensi ini menunjukan gaya kepemimpinan apa yang ada di organisasi, model kepemimpinan dan persepsi bawahan terhadap model kepemimpinan yang ada.

3. Pengelolaan Karyawan

Dimensi ini menunjukan cara pengelolaan karyawan di dalam sebuah organisasi, baik pengelolaan kelompok maupun secara individu.

4. Perekat Organisasi

Dimensi ini menunjukan nilai-nilai apa yang dipakai dalam merekatkan segala sumber daya yang ada di sebuah organisasi.

5. Penekanan Strategis

Dimensi ini berfokus pada cara organisasi untuk memfokuskan segala elemen di dalam pencapaian misi strategis yang ada.

6. Kriteria Sukses

Dimensi ini berfokus pada bagaimana perusahaan menetapkan standar di dalam pencapaian tujuan yang ada.

OCAI atau Organizational Culture Assessment Instrumentmerupakan instrumen untuk memberi penilaian terhadap budaya perusahaan saat ini dan memetakan keinginan perubahan organisasi yang dikembangkan dan diperkenalkan oleh peneliti Amerika, Kim S. Cameron dan Robert E. Quinn.Uji coba skala OCAI dilakukan Quinn dan Spreitzer (1991) dalam penelitiannya 796 eksekutif dari 86 perusahaan umum yang berbeda. Uji reliabilitas yang dilakukan menggunakan nilai koefisien alpha cronbach untuk setiap tipe budaya. Hasilnya tiap koefisien secara statistik signifikan saat dibandingkan dengan standar normal reliabilitas. Nilai koefisiennya adalah 0,74 untuk clan culture, 0,79 untuk adhocracy culture, 0,73 untuk hierarchy culture dan 0,71 untuk market culture. 
Penelitian Cameron dan Freeman (1991) menghasilkan bukti untuk validitas dari OCAI dalam studi mereka tentang budaya organisasi di 334 lembaga pendidikan tinggi. Bukti untuk validitas dari instrumen budaya ini adalah pada saat tipe budaya cocok dengan efektivitas utama seperti pengambilan keputusan, struktur dan strategi yang digunakan dari sebuah organisasi yang maju. Organisasi yang memiliki tipe budaya clan culture memiliki efektivitas paling utama yaitu dari kinerja yang berkaitan dengan moral, kepuasan, komunikasi intern dan dukungan, segala atributnya konsisten dengan nilai clan culture. Sebanyak 24 Organisasi dengan tipe budaya adhocrary culture memiliki efektivitas paling utama yaitu dari kinerja yang berkaitan dengan adaptasi, keterbukaan system dan inovasi, segala atribut konsisten dengan nilai adhocracy culture. Organisasi dengan tipe budaya market culture memiliki efektifitas paling utama yaitu dari kinerja yang berkaitan dengan kemampuan untuk memperoleh sumber daya yang dibutuhkan seperti pendapatan dan sumber daya dengan kemampuan yang baik, segala atribut konsisten dengan nilai market culture. Sedangkan organisasi dengan tipe budaya hierarchy culture tidak unggul dalam kinerja utama.

\section{METODOLOGI PENELITIAN}

Teknik pengambilan sampel menggunakan metode stratified random sampling proporsional yang terdiri dari 6 Manajer Umum, 20 Manajer Senior, 34 Kepala Bagian, 33 Kepala Tim dan 13 Staf. Instrumen yang digunakan dalam penelitian ini adalah Organizational Culture Assessment Intstrument (OCAI), yang memetakan budaya organisasi menjadi empat jenis budaya organisasi melalui pengukuran enam dimensi, yaitu karakteristik dominan, kepemimpinan organisasi, manajemen karyawan, perekat organisasi, dan kriteria keberhasilan. Teknik pengumpulan data yang digunakan adalah kuesioner.

\section{HASIL DAN PEMBAHASAN}

\section{Uji Instrumen Penelitian}

Instrumen dikatakan baik apabila memenuhi tiga persyaratan utama yaitu (1) valid atau sahih, (2) reliabel atau andal, dan (3) praktis oleh Cooper dan Sehindler (2006). Bilamana alat ukur yang digunakan tidak valid atau tidak dapat dipercaya dan tidak andal atau reliabel, maka hasil penelitian tidak akan menggambarkan keadaan yang sesungguhnya. Karena itu, untuk menguji kuesioner sebagai instrumen penelitian maka digunakan uji validitas (test of validity) dan uji reliabilitas (test of reliability). 


\section{Uji Validitas}

Uji validitas dipergunakan untuk atau terpercaya. Valid tidaknya suatu mengetahui apakah instrumen yang digunakan dalam penelitian sudah valid instrument dapat diketahui dengan cara melihat hasil penelitian yang valid bila nilai $\mathrm{r}_{\text {hitung }}>\mathrm{r}_{\text {tabel }}$.

Tabel 1

Hasil Uji Validitas Budaya Clan

\begin{tabular}{cccccccc} 
Item & $\begin{array}{c}\text { R tabel } \\
(\mathrm{df}=104), \text { eror } \\
10 \%\end{array}$ & Correlation & Ket. & Item & $\begin{array}{c}\text { R tabel } \\
(\mathrm{df}=104) \text { eror } \\
10 \%\end{array}$ & Correlation & Ket. \\
A1 & 0.16016 & 0.494 & Valid & $\mathrm{C} 1$ & 0.16016 & 0.610 & Valid \\
\hline A2 & 0.16016 & 0.586 & Valid & $\mathrm{C} 2$ & 0.16016 & 0.766 & Valid \\
\hline A3 & 0.16016 & 0.665 & Valid & C3 & 0.16016 & 0.798 & Valid \\
\hline A4 & 0.16016 & 0.643 & Valid & C4 & 0.16016 & 0.791 & Valid \\
\hline A5 & 0.16016 & 0.608 & Valid & C5 & 0.16016 & 0.712 & Valid \\
\hline A6 & 0.16016 & 0.646 & Valid & C6 & 0.16016 & 0.652 & Valid \\
\hline B1 & 0.16016 & 0.619 & Valid & D1 & 0.16016 & 0.457 & Valid \\
\hline B2 & 0.16016 & 0.671 & Valid & D2 & 0.16016 & 0.643 & Valid \\
\hline B3 & 0.16016 & 0.574 & Valid & D3 & 0.16016 & 0.680 & Valid \\
\hline B4 & 0.16016 & 0.722 & Valid & D4 & 0.16016 & 0.555 & Valid \\
\hline B5 & 0.16016 & 0.624 & Valid & D5 & 0.16016 & 0.664 & Valid \\
\hline B6 & 0.16016 & 0.598 & Valid & D6 & 0.16016 & 0.530 & Valid \\
\hline
\end{tabular}

Sumber : Data Primer Diolah, 2019

Pada Tabel 1 di atas, menunjukkan hasil uji validitas dari tipe-tipe budaya, dimana $r_{\text {tabel }}$ untuk sampel sebanyak 106 atau df sebanyak 104 dengan tingkat eror $10 \%$ adalah 0.16016. Seluruh instrumen pada tipe budaya Clan memiliki koefisien korelasi $r_{\text {hitung }}$ lebih besar dari pada $r_{\text {tabel }}$. Sehingga dapat disimpulkan bahwa semua item pernyataan pada keempat tipe budaya yang digunakan sebagai instrumen dalam penelitian ini adalah valid dan layak dianalisis lebih lanjut.

\section{Uji Reliabilitas}

Cameron dan Quinn

(1999) mengemukakan bahwa reliabilitas mengacu pada sejauh mana instrumen mengukur jenis budaya secara konsisten. OCAI sebagai instrumen yang mampu memetakan budaya organisasi di suatu perusahaan yang telah diujicobakan di beberapa penelitian. Uji coba mulai dari level staff hingga top management mendapatkan kisaran realibilitas 0,6 sampai 0,8 ini menyatakan bahwa alat ini cukup mampu menunjukkan konsistensi dari sebuah alat ukur. Menurut Wagiran (2014), uji reliabilitas dengan rumus Alpha Cronbach, koefisien Alpha Cronbach merupakan model internal concistency score berdasarkan korelasi antara butirbutir yang ekuivalen. Skala pengukuran yang reliabel sebaiknya memiliki alpha cronbach minimal 0,5. Hasil uji reliabilitas 
dalam penelitian ini disajikan pada tabel 2 . Hasil uji reliabilitas menggunakan Cronbach Alpha dengan ketentuan jika nilai lebih besar dari 0,50 menandakan kuesioner tersebut reliabel atau handal. Sedangkan pada perhitungan nilai Alpha cronbach's dari Tabel 2 di atas menunjukkan seluruh indikator variabel yang dijadikan sebagai instrumen dalam penelitian ini adalah cut of value $\geq 0.50$. Hal tersebut menandakan semua item pernyataan yang dijadikan instrumen dapat dipercaya keandalanya. Persyaratan nilai alpha cronbach's telah terpenuhi oleh semua indikator variabel dengan nilai berada diatas 0.50 sehingga instrumen layak untuk dianalisis lebih lanjut.

Tabel 2

Hasil Uji Reliabilitas

\begin{tabular}{cccc} 
Tipe Budaya & Item (Butir)Dimensi & $\begin{array}{c}\text { Cronbanch's } \\
\text { Alpha }\end{array}$ & Keterangan \\
Budaya A (Clan) & $1 \mathrm{~A}, 2 \mathrm{~A}, 3 \mathrm{~A}, 4 \mathrm{~A}, 5 \mathrm{~A}, 6 \mathrm{~A}$ & 0.654 & Reliabel \\
\hline $\begin{array}{c}\text { Budaya B } \\
\text { (Adhocracy) }\end{array}$ & $1 \mathrm{~A}, 2 \mathrm{~A}, 3 \mathrm{~A}, 4 \mathrm{~A}, 5 \mathrm{~A}, 6 \mathrm{~A}$ & 0.706 & Reliabel \\
\hline Budaya C (Market) & $1 \mathrm{~A}, 2 \mathrm{~A}, 3 \mathrm{~A}, 4 \mathrm{~A}, 5 \mathrm{~A}, 6 \mathrm{~A}$ & 0.815 & Reliabel \\
\hline Budaya D (Hierarchy) & $1 \mathrm{~A}, 2 \mathrm{~A}, 3 \mathrm{~A}, 4 \mathrm{~A}, 5 \mathrm{~A}, 6 \mathrm{~A}$ & 0.735 & Reliabel \\
\hline Sumber : Data Primer Diolah, 2019 & &
\end{tabular}

Deskripsi Budaya Organisasi yang Saat Ini Dirasakan Level Karyawan Eselon 3

Berdasarkan Tabel 3, hasil skor OCAI Yang Saat Ini Dirasakan Karyawan Eselon 3 PT Semen Indonesia (Persero) Tbk., menunjukkan bahwa urutan pertama tipe budaya organisasi yang paling dirasakan saat ini oleh Head of Section adalah tipe budaya organisasi Market. Di urutan kedua, disusul dengan tipe budaya organisasi Hierarchy, urutan ketiga tipe budaya organisasi Adhocracy dan urutan keempat yaitu tipe budaya organisasi Clan. Tabel 3 juga menunjukkan bahwa pada tipe budaya Market dimensi yang paling dirasakan saat ini oleh Karyawan Eselon 3 adalah dimensi pengelolaan karyawan. Karyawan Eselon 3 merasakan sangat dominan pada gaya manajemen perusahaan yang dicirikan dengan tuntutan yang tinggi, sifat kompetitif dan pencapaian hasil.

Tabel 3

Hasil Skor OCAI Yang Saat Ini Dirasakan Karyawan Eselon 3

\begin{tabular}{|c|c|c|c|c|c|c|}
\hline $\begin{array}{c}\text { Budaya } \\
\text { Organisasi }\end{array}$ & Dimensi & $\begin{array}{c}\text { Mean/ } \\
\text { Item Dimensi }\end{array}$ & $\begin{array}{c}\text { Std. } \\
\text { Deviation }\end{array}$ & $\begin{array}{l}\text { Peringkat } \\
\text { Dimensi }\end{array}$ & Mean & $\begin{array}{l}\text { Peringkat } \\
\text { Tipe Budaya }\end{array}$ \\
\hline \multirow{6}{*}{ Clan (A) } & $1 \mathrm{~A}$ & 25.59 & 1 & 7.04 & \multirow{6}{*}{23.06} & \multirow{6}{*}{4} \\
\hline & $2 \mathrm{~A}$ & 22.00 & 4 & 7.50 & & \\
\hline & $3 \mathrm{~A}$ & 21.73 & 6 & 6.22 & & \\
\hline & $4 \mathrm{~A}$ & 25.05 & 2 & 9.14 & & \\
\hline & $5 \mathrm{~A}$ & 21.85 & 5 & 8.60 & & \\
\hline & $6 \mathrm{~A}$ & 22.12 & 3 & 8.44 & & \\
\hline
\end{tabular}




\begin{tabular}{|c|c|c|c|c|c|c|}
\hline \multirow{6}{*}{$\begin{array}{l}\text { Adhocracy } \\
\text { (B) }\end{array}$} & $1 \mathrm{~B}$ & 23.32 & 5 & 7.58 & \multirow{6}{*}{23.42} & \multirow{6}{*}{3} \\
\hline & $2 \mathrm{~B}$ & 23.79 & 4 & 6.94 & & \\
\hline & $3 B$ & 24.00 & 3 & 7.50 & & \\
\hline & $4 B$ & 25.44 & 1 & 10.2 & & \\
\hline & $5 B$ & 24.76 & 2 & 7.90 & & \\
\hline & $6 B$ & 22.15 & 6 & 6.92 & & \\
\hline \multirow{6}{*}{ Market (C) } & $1 \mathrm{C}$ & 28.09 & 2 & 8.96 & \multirow{6}{*}{27.29} & \multirow{6}{*}{1} \\
\hline & $2 \mathrm{C}$ & 29.47 & 1 & 8.30 & & \\
\hline & $3 \mathrm{C}$ & 25.47 & 6 & 8.53 & & \\
\hline & $4 \mathrm{C}$ & 25.94 & 5 & 10.42 & & \\
\hline & $5 \mathrm{C}$ & 27.50 & 3 & 9.60 & & \\
\hline & $6 \mathrm{C}$ & 27.29 & 4 & 6.50 & & \\
\hline \multirow{6}{*}{ Hierarchy (D) } & $1 \mathrm{D}$ & 23.00 & 6 & 8.50 & \multirow{6}{*}{25.735} & \multirow{6}{*}{2} \\
\hline & $2 \mathrm{D}$ & 24.74 & 4 & 5.98 & & \\
\hline & $3 \mathrm{D}$ & 28.79 & 1 & 7.77 & & \\
\hline & $4 \mathrm{D}$ & 23.56 & 5 & 7.16 & & \\
\hline & $5 \mathrm{D}$ & 25.88 & 3 & 6.42 & & \\
\hline & $6 \mathrm{D}$ & 28.44 & 2 & 9.50 & & \\
\hline
\end{tabular}

Sumber : Data Primer Diolah, 2019

Deskripsi Budaya Organisasi yang Saat Ini DirasakanKaryawan Eselon 4

Tabel 4 menunjukkan hasil Skor OCAI Yang Saat Ini Dirasakan Karyawan Eselon 4 PT Semen Indonesia (Persero) Tbk., menunjukkan urutan pertama tipe budaya organisasi yang paling dirasakan saat ini oleh Head of Team adalah tipe budaya organisasi hierarchy. Di urutan kedua, disusul dengan tipe budaya organisasi market, urutan ketiga tipe budaya organisasi adhocracy dan urutan paling sedikit dirasakan yaitu tipe budaya clan.

Berdasarkan Tabel 4 dapat diketahui bahwa pada tipe budaya hierarchy, dimensi yang paling dirasakan saat ini oleh Karyawan Eselon 4 atau Kepala Seksi PT Semen Indonesia (Persero) Tbk. adalah dimensi gaya kepemimpinan organisasi dengan skor rata-rata 28.82. Head of Team sangat merasakan gaya kepemimpinan PT Semen Indonesia umumnya menekankan pentingnya koordinasi dan kontrol yang baik agar perusahaan berjalan efisien. Selanjutnya, skor dimensi yang tidak kalah signifikan yang dirasakan Kepala Seksi pada tipe budaya hierarchy adalah dimensi penekanan strategis dengan skor rata-rata 28.8 dan perekatan hubungan dalam organisasi dengan skor 28. Kepala Seksi sangat merasakan juga bahwa PT Semen Indonesia merupakan tempat bekerja yang menekankan stabilitas, efisiensi, pengendalian dan pelaksanaan secara lancar sesuai aturan-aturan maupun kebijakan formal. 
Tabel 4

Hasil Skor OCAI Yang Saat Ini Dirasakan Karyawan Eselon 4

\begin{tabular}{|c|c|c|c|c|c|c|}
\hline $\begin{array}{c}\text { Budaya } \\
\text { Organisasi }\end{array}$ & Dimensi & $\begin{array}{c}\text { Mean/ } \\
\text { Item Dimensi }\end{array}$ & $\begin{array}{c}\text { Std. } \\
\text { Deviation }\end{array}$ & $\begin{array}{c}\text { Peringkat } \\
\text { Dimensi }\end{array}$ & Mean & $\begin{array}{l}\text { Peringkat } \\
\text { Tipe Budaya }\end{array}$ \\
\hline \multirow{6}{*}{ Clan (A) } & $1 \mathrm{~A}$ & 24.33 & 6.73 & 1 & \multirow{6}{*}{22.64} & \multirow{6}{*}{4} \\
\hline & $2 \mathrm{~A}$ & 21.90 & 8.85 & 5 & & \\
\hline & $3 \mathrm{~A}$ & 22.55 & 8.56 & 4 & & \\
\hline & $4 \mathrm{~A}$ & 24.12 & 8.77 & 2 & & \\
\hline & $5 \mathrm{~A}$ & 20.33 & 7.42 & 6 & & \\
\hline & $6 \mathrm{~A}$ & 22.58 & 10.55 & 3 & & \\
\hline \multirow{6}{*}{$\begin{array}{l}\text { Adhocracy } \\
\text { (B) }\end{array}$} & $1 \mathrm{~B}$ & 22.36 & 7.86 & 3 & \multirow{6}{*}{22.68} & \multirow{6}{*}{3} \\
\hline & $2 \mathrm{~B}$ & 24.18 & 7.32 & 2 & & \\
\hline & $3 B$ & 21.27 & 5.92 & 5 & & \\
\hline & $4 B$ & 21.73 & 7.50 & 4 & & \\
\hline & $5 B$ & 25.36 & 7.64 & 1 & & \\
\hline & $6 \mathrm{~B}$ & 21.15 & 7.05 & 6 & & \\
\hline \multirow{6}{*}{ Market (C) } & $1 \mathrm{C}$ & 29.06 & 7.84 & 1 & \multirow{6}{*}{27.14} & \multirow{6}{*}{2} \\
\hline & $2 \mathrm{C}$ & 27.00 & 8.86 & 4 & & \\
\hline & $3 \mathrm{C}$ & 27.36 & 8.76 & 3 & & \\
\hline & $4 \mathrm{C}$ & 26.15 & 9.45 & 5 & & \\
\hline & $5 \mathrm{C}$ & 25.52 & 6.47 & 6 & & \\
\hline & $6 \mathrm{C}$ & 27.76 & 8.49 & 2 & & \\
\hline \multirow{6}{*}{ Hierarchy (D) } & $1 \mathrm{D}$ & 24.24 & 7.08 & 6 & \multirow{6}{*}{27.55} & \multirow{6}{*}{1} \\
\hline & $2 \mathrm{D}$ & 26.91 & 7.90 & 4 & & \\
\hline & $3 \mathrm{D}$ & 28.82 & 8.64 & 1 & & \\
\hline & $4 \mathrm{D}$ & 28.00 & 8.13 & 3 & & \\
\hline & $5 \mathrm{D}$ & 28.80 & 9.17 & 2 & & \\
\hline & $6 \mathrm{D}$ & 25.52 & 9.71 & 5 & & \\
\hline
\end{tabular}

Sumber : Data Primer Diolah, 2019

\section{Deskripsi Budaya Organisasi yang Saat Ini Dirasakan Karyawan Eselon 5}

Hasil Skor OCAI Karyawan Eselon 5 PT Semen Indonesia (Persero) Tbk. pada tabel 5, menunjukkan bahwa staff perusahaan merasakan perusahaan saat ini lebih menekankan tipe budaya organisasi Hierarchy. Urutan kedua, disusul dengan tipe budaya organisasi Clan, urutan ketiga tipe budaya organisasi Market dan urutan paling sedikit dirasakan yaitu tipe budaya organisasi Adhocracy.
Berdasarkan Tabel 5 di atas, diketahui bahwa tipe budaya hierarchy dimensi paling dirasakan saat ini oleh Karyawan Eselon 5 atau staff di PT Semen Indonesia (Persero) Tbk. yakni dimensi kriteria sukses. Kriteria sukses pada tipe budaya hierarchy merujuk pada PT Semen Indonesia dikatakan berhasil atas dasar tingkat efisiensi. Layanan yang diandalkan, penjadwalan yang baik dan produksi biaya rendah adalah faktor utama. 
Tabel 5

Hasil Skor OCAI Yang Saat Ini Dirasakan Karyawan Eselon 5

\begin{tabular}{|c|c|c|c|c|c|c|}
\hline $\begin{array}{l}\text { Budaya } \\
\text { Organisasi }\end{array}$ & Dimensi & $\begin{array}{c}\text { Mean/ } \\
\text { Item Dimensi }\end{array}$ & $\begin{array}{c}\text { Std. } \\
\text { Deviation }\end{array}$ & $\begin{array}{l}\text { Peringkat } \\
\text { Dimensi }\end{array}$ & Mean & $\begin{array}{c}\text { Peringkat } \\
\text { Tipe Budaya }\end{array}$ \\
\hline \multirow{6}{*}{ Clan (A) } & $1 \mathrm{~A}$ & 25.69 & 8.64 & 4 & \multirow{6}{*}{25.58} & \multirow{6}{*}{$-x+4+2$} \\
\hline & $2 \mathrm{~A}$ & 26.62 & 8.50 & 2 & & \\
\hline & $3 \mathrm{~A}$ & 28.00 & 8.50 & 1 & & \\
\hline & $4 \mathrm{~A}$ & 26.00 & 8.96 & 3 & & \\
\hline & $5 \mathrm{~A}$ & 21.54 & 7.66 & 6 & & \\
\hline & $6 \mathrm{~A}$ & 25.62 & 9.56 & 5 & & \\
\hline \multirow{6}{*}{ Adhocracy (B) } & $1 \mathrm{~B}$ & 21.08 & 7.65 & 4 & \multirow{6}{*}{21.7} & \multirow{6}{*}{4} \\
\hline & $2 \mathrm{~B}$ & 18.69 & 6.99 & 6 & & \\
\hline & $3 \mathrm{~B}$ & 20.08 & 7.09 & 5 & & \\
\hline & $4 B$ & 24.38 & 8.50 & 1 & & \\
\hline & $5 B$ & 24.15 & 7.40 & 2 & & \\
\hline & $6 \mathrm{~B}$ & 21.62 & 7.95 & 3 & & \\
\hline \multirow{6}{*}{ Market (C) } & $1 \mathrm{C}$ & 25.31 & 9.66 & 3 & \multirow{6}{*}{25.4} & \multirow{6}{*}{3} \\
\hline & $2 \mathrm{C}$ & 29.54 & 10.50 & 1 & & \\
\hline & $3 \mathrm{C}$ & 23.46 & 6.42 & 5 & & \\
\hline & $4 \mathrm{C}$ & 24.85 & 6.14 & 4 & & \\
\hline & $5 \mathrm{C}$ & 26.08 & 5.79 & 2 & & \\
\hline & $6 \mathrm{C}$ & 23.30 & 8.24 & 6 & & \\
\hline \multirow{6}{*}{ Hierarchy (D) } & $1 \mathrm{D}$ & 27.90 & 6.90 & 4 & \multirow{6}{*}{27.3} & \multirow{6}{*}{1} \\
\hline & $2 \mathrm{D}$ & 25.15 & 9.62 & 5 & & \\
\hline & $3 \mathrm{D}$ & 28.50 & 15.50 & 2 & & \\
\hline & $4 \mathrm{D}$ & 24.76 & 9.80 & 6 & & \\
\hline & $5 \mathrm{D}$ & 28.20 & 10.30 & 3 & & \\
\hline & $6 \mathrm{D}$ & 29.46 & 9.40 & 1 & & \\
\hline
\end{tabular}

Sumber : Data Primer Diolah, 2019

Deskripsi Budaya Organisasi Yang Diharapkan Seluruh Karyawan Eselon 3

Berdasarkan Tabel 6 Hasil Skor OCAI Yang Diharapkan Karyawan Eselon 3 PT Semen Indonesia (Persero) Tbk., dapat diketahui bahwa Head of Section mengharapkan tipe budaya Market, pada urutan kedua yaitu tipe budaya Clan, urutan ketiga yaitu Adhocracy dan urutan paling terakhir yaitu tipe budaya Hierarchy. Tipe budaya Market dimensi yang paling diharapkan oleh Head of Section PT Semen Indonesia (Persero)
Tbk. adalah dimensi kepemimpinan organisasi dan kriteria sukses perusahaan. Dimensi kepemimpinan organisasi pada tipe budaya Market yang diharapkan Head of Section pada PT Semen Indonesia adalah diharapkan gaya kepemimpinan di perusahaan berfokus pada kinerja yang nyata, penetapan target yang menantang, agresif dan berorientasi pada hasil. Sedangkan dimensi kriteria sukses yang diharapkan Head of Section adalah PT Semen Indonesia dicirikan berhasil jika 
mampu berkompetisi dengan pesaing dan pasar merupakan faktor utama. memenangkannya serta kepemimpinan

Tabel 6

Hasil Skor OCAI Yang Diharapkan Karyawan Eselon 3

\begin{tabular}{|c|c|c|c|c|c|c|}
\hline $\begin{array}{c}\text { Budaya } \\
\text { Organisasi }\end{array}$ & Dimensi & $\begin{array}{c}\text { Mean/ } \\
\text { Item Dimensi }\end{array}$ & $\begin{array}{c}\text { Std. } \\
\text { Deviation }\end{array}$ & $\begin{array}{l}\text { Peringkat } \\
\text { Dimensi }\end{array}$ & Mean & $\begin{array}{l}\text { Peringkat } \\
\text { Tipe Budaya }\end{array}$ \\
\hline \multirow{6}{*}{ Clan (A) } & $1 \mathrm{~A}$ & 21.38 & 7.13 & 6 & \multirow{6}{*}{25.04} & \multirow{6}{*}{2} \\
\hline & $2 \mathrm{~A}$ & 25.94 & 7.10 & 2 & & \\
\hline & $3 \mathrm{~A}$ & 25.76 & 7.95 & 3 & & \\
\hline & $4 \mathrm{~A}$ & 26.94 & 7.54 & 1 & & \\
\hline & $5 \mathrm{~A}$ & 25.00 & 8.40 & 5 & & \\
\hline & $6 \mathrm{~A}$ & 25.21 & 8.65 & 4 & & \\
\hline \multirow{6}{*}{$\begin{array}{l}\text { Adhocracy } \\
\text { (B) }\end{array}$} & $1 \mathrm{~B}$ & 29.00 & 9.84 & 1 & \multirow{6}{*}{24.68} & \multirow{6}{*}{3} \\
\hline & $2 \mathrm{~B}$ & 24.50 & 7.99 & 4 & & \\
\hline & $3 \mathrm{~B}$ & 20.26 & 8.36 & 6 & & \\
\hline & $4 B$ & 25.82 & 12.08 & 3 & & \\
\hline & $5 B$ & 27.20 & 8.74 & 2 & & \\
\hline & $6 B$ & 21.26 & 9.70 & 5 & & \\
\hline \multirow{6}{*}{ Market (C) } & $1 \mathrm{C}$ & 26.22 & 11.26 & 3 & \multirow{6}{*}{26.14} & \multirow{6}{*}{1} \\
\hline & $2 \mathrm{C}$ & 25.74 & 9.45 & 4 & & \\
\hline & $3 \mathrm{C}$ & 27.70 & 11.20 & 1 & & \\
\hline & $4 \mathrm{C}$ & 25.32 & 9.85 & 5 & & \\
\hline & $5 \mathrm{C}$ & 24.35 & 9.43 & 6 & & \\
\hline & $6 \mathrm{C}$ & 27.50 & 10.75 & 2 & & \\
\hline \multirow{6}{*}{ Hierarchy (D) } & $1 \mathrm{D}$ & 23.35 & 7.69 & 6 & \multirow{6}{*}{24.14} & \multirow{6}{*}{4} \\
\hline & $2 \mathrm{D}$ & 23.82 & 8.62 & 3 & & \\
\hline & $3 \mathrm{D}$ & 26.26 & 9.50 & 1 & & \\
\hline & $4 \mathrm{D}$ & 21.91 & 6.98 & 5 & & \\
\hline & $5 \mathrm{D}$ & 23.44 & 6.55 & 4 & & \\
\hline & $6 \mathrm{D}$ & 26.03 & 10.90 & 2 & & \\
\hline
\end{tabular}

Sumber : Data Primer Diolah, 2019

\section{Deskripsi Budaya Organisasi Yang} Diharapkan Karyawan Eselon 4

Hasil Skor OCAI Diharapkan Karyawan Eselon 4 PT Semen Indonesia (Persero) Tbk., dapat diketahui bahwa Head of Team mengharapkan tipe budaya Clan. Di urutan kedua yaitu tipe budaya Market, urutan ketiga yaitu Adhocracy dan Hierarchy.
Tabel 7 di bawah ini juga menunjukkan bahwa pada tipe budaya Clan dimensi yang paling diharapkan oleh Head of Team PT Semen Indonesia (Persero) Tbk dimensi kepemimpinan organisasi, dengan gaya kepemimpinan di perusahaan yang bersifat membimbing, memberi pengajaran, memberikan teladan, mentoring, mamfasilitasi atau memelihara. 
Tabel 7

Hasil Skor OCAI Yang Diharapkan Karyawan Eselon 4

\begin{tabular}{|c|c|c|c|c|c|c|}
\hline $\begin{array}{l}\text { Budaya } \\
\text { Organisasi }\end{array}$ & Dimensi & $\begin{array}{c}\text { Mean/ } \\
\text { Item Dimensi }\end{array}$ & $\begin{array}{c}\text { Std. } \\
\text { Deviation }\end{array}$ & $\begin{array}{l}\text { Peringkat } \\
\text { Dimensi }\end{array}$ & Mean & $\begin{array}{l}\text { Peringkat } \\
\text { Tipe Budaya }\end{array}$ \\
\hline \multirow{6}{*}{ Clan (A) } & $1 \mathrm{~A}$ & 23.94 & 7.63 & 6 & \multirow{6}{*}{25.62} & \multirow{6}{*}{$-1+4+2$} \\
\hline & $2 \mathrm{~A}$ & 25.85 & 6.63 & 3 & & \\
\hline & $3 \mathrm{~A}$ & 27.45 & 7.51 & 1 & & \\
\hline & $4 \mathrm{~A}$ & 26.18 & 8.20 & 2 & & \\
\hline & $5 \mathrm{~A}$ & 24.52 & 6.74 & 5 & & \\
\hline & $6 \mathrm{~A}$ & 25.75 & 10.34 & 4 & & \\
\hline \multirow{6}{*}{ Adhocracy (B) } & $1 \mathrm{~B}$ & 26.91 & 6.80 & 1 & \multirow{6}{*}{24.46} & \multirow{6}{*}{3} \\
\hline & $2 B$ & 24.91 & 9.16 & 3 & & \\
\hline & $3 B$ & 22.88 & 6.60 & 5 & & \\
\hline & $4 B$ & 24.36 & 5.38 & 4 & & \\
\hline & $5 B$ & 26.42 & 8.44 & 2 & & \\
\hline & $6 \mathrm{~B}$ & 21.30 & 6.17 & 6 & & \\
\hline \multirow{6}{*}{ Market (C) } & $1 \mathrm{C}$ & 25.67 & 8.39 & 2 & \multirow{6}{*}{25.45} & \multirow{6}{*}{2} \\
\hline & $2 \mathrm{C}$ & 24.52 & 7.47 & 5 & & \\
\hline & $3 \mathrm{C}$ & 23.90 & 9.17 & 6 & & \\
\hline & $4 \mathrm{C}$ & 24.58 & 8.66 & 4 & & \\
\hline & $5 \mathrm{C}$ & 25.00 & 7.67 & 3 & & \\
\hline & $6 \mathrm{C}$ & 29.00 & 7.38 & 1 & & \\
\hline \multirow{6}{*}{ Hierarchy (D) } & $1 \mathrm{D}$ & 23.48 & 9.02 & 6 & \multirow{6}{*}{24.46} & \multirow{6}{*}{3} \\
\hline & $2 \mathrm{D}$ & 24.73 & 7.77 & 3 & & \\
\hline & $3 \mathrm{D}$ & 25.76 & 8.99 & 1 & & \\
\hline & $4 \mathrm{D}$ & 24.88 & 9.87 & 2 & & \\
\hline & $5 \mathrm{D}$ & 24.00 & 10.13 & 4 & & \\
\hline & $6 \mathrm{D}$ & 23.90 & 7.68 & 5 & & \\
\hline
\end{tabular}

Sumber : Data Primer Diolah, 2018

\section{Deskripsi Budaya Organisasi Yang diharapkan Karyawan Eselon 5}

Hasil Skor OCAI Yang Diharapkan Karyawan Eselon 5 PT Semen Indonesia (Persero) Tbk. menunjukkan bahwa karyawan eselon 5 atau staff mengharapkan tipe budaya Clan dalam perusahaan. Selanjutnya di urutan kedua, eselon 5 mengharapkan tipe budaya Adhocracy. Tabel 8 berikut juga menunjukkan bahwa pada tipe budaya
Clan dimensi yang paling diharapkan oleh karyawan eselon 5PT Semen Indonesia (Persero) Tbk. adalah dimensi karakteristik dominan perusahaan. Dimensi karakteristik dominan pada tipe budaya Clan adalah dimana para staff perusahaan berharap PT Semen Indonesia kedepannya merupakan tempat bekerja yang nyaman, seperti keluarga besar, para karyawan berbagi banyak hal mengenai diri dan kehidupan mereka. 
Tabel 8

Hasil Skor OCAI Yang Diharapkan Karyawan Eselon 5

\begin{tabular}{|c|c|c|c|c|c|c|}
\hline $\begin{array}{c}\text { Budaya } \\
\text { Organisasi }\end{array}$ & Dimensi & $\begin{array}{c}\text { Mean/ } \\
\text { Item Dimensi }\end{array}$ & $\begin{array}{c}\text { Std. } \\
\text { Deviation }\end{array}$ & $\begin{array}{l}\text { Peringkat } \\
\text { Dimensi }\end{array}$ & Mean & $\begin{array}{l}\text { Peringkat } \\
\text { Tipe Budaya }\end{array}$ \\
\hline \multirow{6}{*}{ Clan (A) } & $1 \mathrm{~A}$ & 29.69 & 6.09 & 1 & \multirow{6}{*}{27.69} & \multirow{6}{*}{1} \\
\hline & $2 \mathrm{~A}$ & 28.62 & 3.7 & 2 & & \\
\hline & $3 \mathrm{~A}$ & 26.46 & 8.08 & 5 & & \\
\hline & $4 \mathrm{~A}$ & 28.46 & 5.91 & 3 & & \\
\hline & $5 \mathrm{~A}$ & 25.62 & 7.05 & 6 & & \\
\hline & $6 \mathrm{~A}$ & 27.31 & 8.06 & 4 & & \\
\hline \multirow{6}{*}{ Adhocracy (B) } & $1 \mathrm{~B}$ & 25.92 & 9.67 & 5 & \multirow{6}{*}{26.5} & \multirow{6}{*}{2} \\
\hline & $2 \mathrm{~B}$ & 27.92 & 7.49 & 2 & & \\
\hline & $3 B$ & 26.15 & 9.93 & 4 & & \\
\hline & $4 B$ & 28.31 & 7.84 & 1 & & \\
\hline & $5 B$ & 27.54 & 6.19 & 3 & & \\
\hline & $6 B$ & 23.15 & 5.94 & 6 & & \\
\hline \multirow{6}{*}{ Market (C) } & $1 \mathrm{C}$ & 23.23 & 6.69 & 4 & \multirow{6}{*}{23.47} & \multirow{6}{*}{3} \\
\hline & $2 \mathrm{C}$ & 21.62 & 5.97 & 6 & & \\
\hline & $3 \mathrm{C}$ & 23.69 & 7.66 & 3 & & \\
\hline & $4 \mathrm{C}$ & 23.08 & 6.3 & 5 & & \\
\hline & $5 \mathrm{C}$ & 23.77 & 7.28 & 2 & & \\
\hline & $6 \mathrm{C}$ & 25.46 & 7.1 & 1 & & \\
\hline \multirow{6}{*}{ Hierarchy (D) } & $1 \mathrm{D}$ & 21.15 & 4.4 & 5 & \multirow{6}{*}{22.33} & \multirow{6}{*}{4} \\
\hline & $2 \mathrm{D}$ & 21.85 & 5.26 & 4 & & \\
\hline & $3 \mathrm{D}$ & 23.69 & 8.83 & 2 & & \\
\hline & $4 \mathrm{D}$ & 20.15 & 7.27 & 6 & & \\
\hline & $5 \mathrm{D}$ & 23.08 & 3.77 & 3 & & \\
\hline & $6 \mathrm{D}$ & 24.08 & 5.33 & 1 & & \\
\hline
\end{tabular}

Sumber : Data Primer Diolah, 2018

Perbandingan Budaya PT Semen Indonesia (Persero) Tbk. yang Dirasakan Berdasarkan Persepsi Antar Level Jabatan di PT Semen Indonesia (Persero) Tbk.

Perbandingan Hasil Skor OCAI Yang Diharapkan Seluruh Karyawan PT Semen Indonesia (Persero) Tbk., mulai dari eselon 3 sampai 5, dapat diketahui bahwa saat ini level jabatan yang dominan merasakan tipe budaya marketberada di posisi level jabatan eselon 3, Sedangkan level jabatan eselon 4 dan 5 dominan mengharapkan tipe budaya Hierarchy, seperti terlihat dalam tabel 9.Perbandingan Hasil Skor OCAI yang diharapkan Seluruh Karyawan PT Semen Indonesia, mulai dari eselon 3 sampai 5, dapat diketahui bahwa saat ini level jabatan yang dominan merasakan tipe budaya clan berada di posisi level jabatan eselon 4 dan eselon 5. Sedangkan level jabatan eselon 3 mengharapkan tipe budaya market. 
Tabel 9

Perbandingan Hasil Skor OCAI Budaya Yang Diharapkan Seluruh Karyawan

\begin{tabular}{ccccc|cccc} 
Tingkat & \multicolumn{3}{c}{ Budaya Yang Diharapkan } & \multicolumn{4}{c}{ Budaya Yang Diharapkan } \\
Jabatan & $C$ & $A$ & $M$ & $H$ & $C$ & $A$ & $M$ & 24.10 \\
Eselon 3 & 23.06 & 23.42 & 27.29 & 25.74 & 25.00 & 24.70 & 26.10 & 24.50 \\
\hline Eselon 4 & 22.64 & 22.68 & 27.14 & 27.55 & 25.60 & 24.50 & 24.40 \\
\hline Eselon 5 & 25.58 & 21.67 & 25.40 & 27.30 & 27.70 & 26.50 & 23.47 & 22.33 \\
\hline
\end{tabular}

Sumber : Data Primer Diolah, 2018

Keterangan:
$C$ : Clan
M : Market
A : Adhocracy
$H$ : Hierarchy

Tanggapan Expert Judgement Budaya PT Semen Indonesia (Persero) Tbk. yang Dirasakan Berdasarkan Persepsi Antar Level Jabatan di PT Semen Indonesia (Persero) Tbk.

Validasi hasil OCAI tentang budaya organisasi yang diharapkan karyawan PT Semen Indonesia (Persero) Tbk. dilakukan dengan berkonsultasi pada pakar atau ahli SDM PT Semen Indonesia (Persero) Tbk. khususnya mengenai budaya perusahaan. Berikut pernyataan Guntoro selaku General Manager of Department Center of Dynamic Learning (CDL) PT Semen Indonesia (Persero) Tbk. periode 2014 2017

"...Apa budaya yang diinginkan atau diharapkan oleh responden, sebenarnya itu sedikit irrelevant. Karena corporate culture atau budaya perusahaan itu yang diharapkan sebenarnya bukan di ambil dari karyawan, tapi yang diharapkan dari manajemen. Artinya, doktrin dari manajemen kalau budaya itu. Sehingga strategi perusahaan mengarahkan".

Berdasarkan judgement di atas, sesuai dengan tujuan penelitian ini bahwa adanya pemetaan ini nantinya diharapkan sebagai masukan kepada pihak manajemen. Dalam hal ini, bukan mendoktrin pihak manajemen untuk menyesuaikan budaya sesuai keinginan karyawan, namun bagaimana manajemen bisa menyatukan karyawan dengan budaya yang telah ditentukan manajemen. Sehingga nantinya strategi perusahaan dapat diaplikasikan dengan mudah karena memiliki mindset yang sama terutama untuk budaya organisasi yang diharapkan mendatang guna pengembangan perusahaan untuk menuju world class company di era revolusi industri 4.0. Dikutip dari Sinergi edisi 18 (2017) [5], yang menyatakan bahwa merujuk hasil penelitian di Harvard University, AS, bahwa perusahaan yang menerapkan corporate culture dengan sangat baik bakal mengalami pertumbuhan beratus-ratus kali lipat dibanding perusahaan yang tidak fokus pada corporate culture. Selanjutnya Guntoro juga menjelaskan mengenai tipe budaya yang paling sesuai ataupun tipe budaya mana yang seharusnya mampu membawa PT Semen Indonesia (Persero) Tbk. mencapai 
program winning culture menuju world class company maupun menghadapi persaingan yang ada nantinya. Guntoro (2018), menyatakan bahwa

"...Nah kemudian dalam rangka menuju world class company, menurut saya sih tetap konsisten antara market dan hierarchy. Biasanya ada sub culture tidak apa-apa. Tapi pada prinsipnya harusnya memang ada satu culture besar, culture yang common culture, kemudian ada sub culture itu diperbolehkan. Nah, di konsep ini Semen Indonesia untuk world class company yang hierarchy ini mungkin manufacturing iya, tetapi manufacturing yang eselonnya di level agak bawah. Artinya eselon 4, 5 itu mungkin memang di pabrik itu harusnya hierarchy. Tapi eselon 3 pabrik pun itu mungkin harus hierarchy iya, tapi agak bergeser juga memperhatikan market. Mangkanya menurut saya, dalam mengarahkan budaya apa yang harus dimiliki oleh sebuah perusahaan untuk world class company itu bias saja sebenarnya tidak satu budaya gitu loh maksud saya.

Berdasarkan judgement di atas, dapat disimpulkan bahwa karyawan PT Semen Indonesia (Persero) Tbk. selaku holding company khususnyasebagai business development, dalam menyatukan anakanak perusahaan nantinya dan dapat bersaing menjadi world class company di era revolusi industri 4.0. Karyawan perusahaan seharusnya memiliki mindset dan mengharapkan tipe budaya market, karenapada prinsipnya budaya sebagai common culture.Sedangkan untuk cluster manufacturing khususnya di eselon 4 dan 5 seharusnya dominan pada tipe budaya hierarchy. Dimana tipe Hierachy sendiri sebagai second atau sub culture disini. Namun sesuai dengan hasil penelitian, karyawan PT Semen Indonesia secara keseluruhan belum memiliki mindset yang sama terutama untuk budaya organisasi yang diharapkan mendatang, utamanya budaya market sebagai commond market dalam menunjang program winning culture menuju world class company.

Berdasarkan judgement di atas, sesuai dengan tujuan penelitian ini bahwa General Manager atau karyawan eselon 1 yang merupakan pemimpin perusahaan secara keseluruhan juga masih belum memiliki mindset yang sama terutama dan menciptakan atmosfir budaya kompetitif di diri mereka agar PT Semen Indonesia (Persero) Tbk. mampu bersaing di era 4.0 industri ke depan dan benar-benar menjadi world class company. Adanya pemetaan ini nantinya diharapkan sebagai masukan kepada pihak manajemen, bagaimana manajemen bisa menciptakan budaya kompetitif lebih dominan lagi dan menyatukan karyawan dengan budaya yang telah ditentukan manajemen. Sehingga nantinya strategi perusahaan dapat diimplementasikan dengan mudah karena memiliki mindset sama terutama untuk budaya organisasi yang diharapkan mendatang guna pengembangan perusahaan untuk menuju world class company di era revolusi industri 4.0. 


\section{KESIMPULAN}

Berdasarkan hasil penelitian dan pembahasan mengenai pemetaan budaya PT Semen Indonesia (Persero) Tbk. menggunakan Organizational Culture Assessment Instrument (OCAI) sebagai rujukan winning culture menuju world class company, maka diperoleh kesimpulan sebagai berikut:

1. Tipe budaya PT Semen Indonesia (Persero) Tbk. yang saat ini dominan dirasakan adalah tipe budaya organisasi hierarchy atau yang dicirikan dengan fokus internal, garis wewenang (authority) pengambilan keputusan yang jelas, adanya standar peraturan, kontrol, formalisasi yang baku, terdapatnya struktur kerja yang jelas dan seluruh anggota organisasi dikendalikan oleh prosedur kerja.

2. Tipe budaya PT Semen Indonesia (Persero) Tbk. yang diharapkan adalah tipe budaya clan, dimana dominan pada pemeliharaan internal organisasi yang fleksibel, partisipatif, kerja tim, program keterlibatan karyawan dan komitmen korporat kepada para karyawan.

3. Berdasarkan pakar ahli dalam penelitian ini, ada dua tipe budaya dalam menunjang PT Semen Indonesia (Persero) Tbk. mencapai program winning culture menuju world class company, Tipe budaya market sebagai budaya utama atau common culture. Sedangkan second culture atau subculture yang dominan adalah tipe budaya hierarchy.

\section{IMPLIKASI PENELITIAN}

General Manager yang merupakan pemimpin perusahaan diharapkan memiliki dan menciptakan budaya yang sesuai, utamanya budaya kompetitif agar PT Semen Indonesia (Persero) Tbk. mampu bersaing di era 4.0 industri ke depan dan benar-benar menjadi world class company.

Pada budaya organisasi secara keseluruhan, hanya eselon 3 atau head section yang dominan mengharapkan budaya market. Adanya perbedaan persepsi ini tentu diharapkan menjadi bahan diskusi oleh internal perusahaan agar terdapat keselarasan budaya di setiap level jabatan sebagai kesiapan agar perusahaan mampu bersaing di era 4.0 industri ke depan dan benar-benar menjadi world class company.

\section{DAFTAR PUSTAKA}

Cameron K, Freeman S. (1991) Cultural Congruence, Strength, and Type: Relationships to Effectiveness. Research in Organizational Change and Development, 5, 23-58. 
Cameron KS, Quinn RE. (2011). Diagnosing and Changing Organizational Culture based on The Competing Values Framework. 3rd edition. USA. Addison-Wesley Publishing Company.Inc.

Cameron KS, and Quinn RE (1999). Diagnosing and Changing Organizational Culture based on The Competing Values Framework. MA: Addison-Wesley.

Cooper DR, Schinder PS. (2006). Metode Riset Bisnis. Volume 2, Edisi 9. Jakarta: PT Media Global Edukasi.

Quinn R, Spreitzer, G. (1991). The Psychometric of the Competing Values Culture Instrument and an Analysis of the Impact of Organizational Culture on Quality of Life. In: Woodman, R.W. and Pasmore, W.A., Eds., Research in Organizational Change and Development, Vol. 5, JAI Press, Greenwich, 115-142.

Sinergi (2017) edisi 18. Gresik: PT. Semen Indonesia

Wagiran. (2014). Implementasi Kurikulum 2013. Temanggung: CV Bahtera Wijaya Perkasa.

Zulfikar RC, Gustomo A. (2014). Analysis on PT. Semen Indonesia Organizational Culture Based on Organizational Cultural Assessment Instrument (OCAI). Journal of Business and Managemet. 3(7), 765-771. 